\title{
Development of Teacher E-Module for Dynamic Balance Movement for Grade 3 Elementary School with Autism
}

\author{
$1^{\text {st }}$ Rama Kurniawan \\ Physical Education, Health and \\ Recreation \\ Universitas Negeri Malang \\ Malang, Indonesia \\ rama.kurniawan.fik@um.ac.id \\ $4^{\text {th }}$ Febrita Paulina Heynoek \\ Physical Education, Health and \\ Recreation \\ Universitas Negeri Malang \\ Malang, Indonesia \\ febrita.paulina.fik@um.ac.id
}

\author{
$2^{\text {nd }}$ Mu'arifin \\ Physical Education, Health and \\ Recreation \\ Universitas Negeri Malang \\ Malang, Indonesia \\ mu'arifin.fik@um.ac.id \\ $5^{\text {th }}$ Cahyo Nugroho Sigit \\ Physical Education, Health and \\ Recreation \\ Universitas Negeri Malang \\ Malang, Indonesia \\ Cahyomalang2020@gmail.com
}

\author{
$3^{\text {rd }}$ Ari Wibowo Kurniawan \\ Physical Education, Health and \\ Recreation \\ Universitas Negeri Malang \\ Malang, Indonesia \\ ari.wibowo.fik@um.ac.id
}

\begin{abstract}
This study aimed to develop a dynamic balance motion learning module for grade 3 teachers of Special Education School with autism. The method in this research was research and development. The data analysis technique used a quantitative descriptive approach in the form of percentages. The development model used the ADDIE model (analysis, design, development, implementation, and evaluation). The research subjects were SLB Autism UM and SLB C Autism Tuban City. The results of small group trials and large group trials showed the feasibility and effectiveness of the module increased from $81 \%$ to $94 \%$ with very valid information. Based on these data, it can be concluded that the dynamic balance motion teacher module for grade 3 students of Special Education School with autism is very valid for use in learning.
\end{abstract}

Keywords- e-module, autism disorder, dynamic balance

\section{INTRODUCTION}

Autism is a pervasive developmental disorder. This developmental disorder includes aspects of communication, social interaction, motor skills, emotions, and interests [1]. Although there is a complex series of disorders in autistic children, autistic children generally have complete limbs. The provision of physical activity with the aim of training and improving motor function in children is manifested in subjects in the curriculum, namely physical education. Physical education is one part of overall education, which has the aim of improving physical fitness, building students' movement skills, thinking skills, social skills, building morals, and a healthy lifestyle, and maintaining a clean environment [2]. Physical education is a compulsory subject that is closely related to the educational process that is carried out consciously and systematically through various physical activities to obtain physical fitness and shape the character of students by having a healthy lifestyle [3]. Based on this opinion, physical education is a compulsory subject in the curriculum which aims to realize physical fitness in individuals by covering aspects of knowledge, skills, and attitudes. The provision of physical education for autistic children is realized through adaptive physical education.

One of the materials in adaptive physical education is gymnastics. A gymnastics is a form of systematic physical movement that can be done on the floor or on a mat in the form of a mat [4]. Children with autism will have difficulty with postural stability, especially when balance tasks present greater sensorimotor challenges on unstable surfaces [5][6][7]. However, the pattern of motion exercises on an unstable surface using foam can improve postural control in autistic children [8]. Based on the dynamic balance motion activity model which includes motion 
in autistic children using dynamic basic movements (refusing, swinging, hovering in the air, turning, and landing) in floor gymnastics activities can improve posture control or balance and present challenges to the movement model performed above. unstable surface. In line with the purpose of physical education, namely physical fitness in individuals which is realized by physical activity. In the learning process, autistic children need relevant teaching media in the form of visual or audiovisual

In the process of learning physical education, children with autism are still constrained by the lack of teaching materials used. Teaching materials are all collections of information that are systematically arranged and needed in a learning process so that the objectives of learning are achieved optimally [9]. One form of teaching media that is often used is the module. The use of learning media, one of which can be in the form of this module, can provide a stimulus to thoughts, feelings, concerns, and interests and so that the learning process can be carried out efficiently. The use of modules in the learning process has the advantage that it can motivate students [10]. To facilitate students and teachers in carrying out the learning process, the developed module is equipped with a QR Code (Quick Response Code) feature. a type of matrix code or barcode with two dimensions [11].The use of this QR Code as a medium to link to a website that contains examples of movement in the material presented through the module.

The problem of the lack of teaching materials that can support the learning process is also strengthened based on the results of a needs analysis questionnaire in the form of a Google Form filled out by 30 teachers at the Special Education School level throughout East Java in September 11, 2021. The results of the data search stated that 17 SLB teachers $(56.77 \%)$ stated that learning Physical Education, Sports, and Health in schools has not been implemented properly. A total of 25 teachers $(83.33 \%)$ experienced problems when teaching these materials. 14 teachers $(46.66 \%)$ used books/modules and 23 teachers $(76.66 \%)$ used motion videos/games as a learning resource for Physical Education (PE) at school. Another result stated that only 11 teachers (36.66\%) stated that they used a module book for learning dynamic balance motion material. A total of 29 teachers $(96.66 \%)$ stated that it was necessary to develop PE learning books/modules in schools.

Based on the background of the problem and the initial needs analysis data that have been described, the researcher seeks to create alternative solutions to these problems through research and development. Therefore, in line with the problems mentioned above, the researcher has conducted research and development with the title "Development of Teacher E-module Material for Dynamic Balance for Class 3
Special Education School Students". The purpose of this research and development is to produce a teaching material product in the form of a teacher e-module with android-based dynamic balance material that is valid, effective, and interesting.

\section{METHOD}

The research method used is a research and development method that aims to develop a product in the form of a dynamic balance motion teacher module for grade 3 Special Education School students with autism. While the research and development model (Research and Development) is carried out using the ADDIE development model which consists of five stages, namely, Analysis (Analysis), Design (Planning), Develop (Development), Implement (Application), Evaluate (Assessment) [12]. The use of the EDDIE model in this study is considered more suitable because the stages in the product development of the ADDIE model are more coherent, as well as the validation and testing stages that make the resulting draft more perfect. The subjects of this study were the Special Education School Autism State University of Malang and Special Education School C Autism Tuban City. The research sampling technique from each school is the purposive sampling technique, where data is taken based on certain criteria and considerations to facilitate researchers in exploring the object or social situation being studied [13]. The sample criteria in this study were the autistic Special Education School PE teachers and $3^{\text {rd }}$-grade autistic Special Education School students.

\section{RESULT}

Based on the results of the initial needs analysis, the need for learning modules that are following the Core Competencies and Basic Competencies of autistic children is very necessary, therefore the development of dynamic balance motion modules is arranged in such a way with simple movements that have been validated by experts. Expert validation consists of media expert validation, material expert validation, and expert validation of the characteristics of autistic children. Based on the results of the validation, the product was then revised according to the input from each validator, after being revised then the product was tested. Small group trials were carried out at Special Education School Autism UM, with the research object being 3 students with autism grade 3 and 6 teachers at Special Education School Autism UM. While the large group trial was conducted at Special Education School C Autism Tuban, with the research objects being 6 students with autism grade 3 and 12 teachers at Special Education School C Autism Tuban. From the two trials, the teacher provided assessments and suggestions through a questionnaire instrument that had been given by the researcher. The 
assessment questionnaire instrument in the form of a statement can then be given a Likert scale score for closed assessment according to what has been determined, namely a score of one.

\section{Validation of Media Expert}

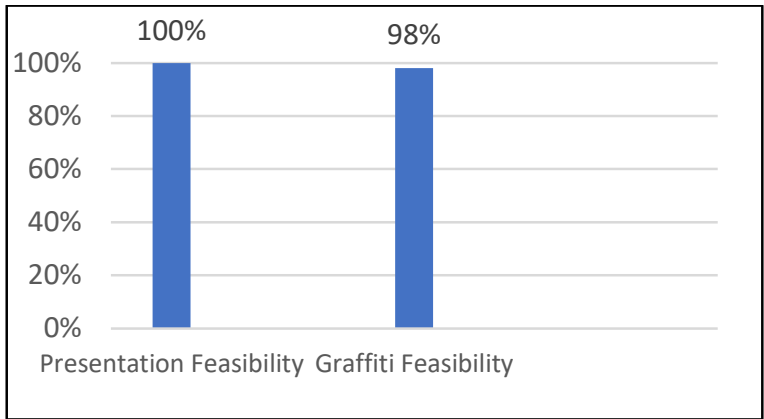

Figure 1. Percentage of media expert justification

Based on the results of the validator's evaluation in the field of media experts, the evaluation is done based on presentation qualification and graphic qualification, for presentation qualification with a value of $100 \%$ is in the category of "very valid" then for graphic qualification assessment get a value of $98 \%$ with the category "very valid". The notes provided by the validator are generally good.

\section{Validation of Content Experts}

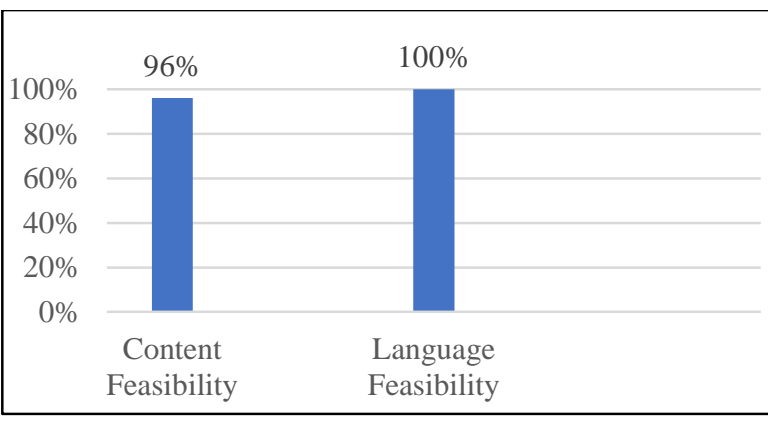

Figure 2. Percentage of content expert justification

Based on the results of the validator's assessment in the field of content experts, the assessment is done based on the feasibility of content and language feasibility, for content feasibility with a value of $96 \%$ is in the category of "very valid" then for language feasibility assessment get a value of $100 \%$ with the category of "very valid". The notes provided by the validator are the specifications of autistic children need to be clarified.

\section{Validation of Expert of Autism Characteristic}

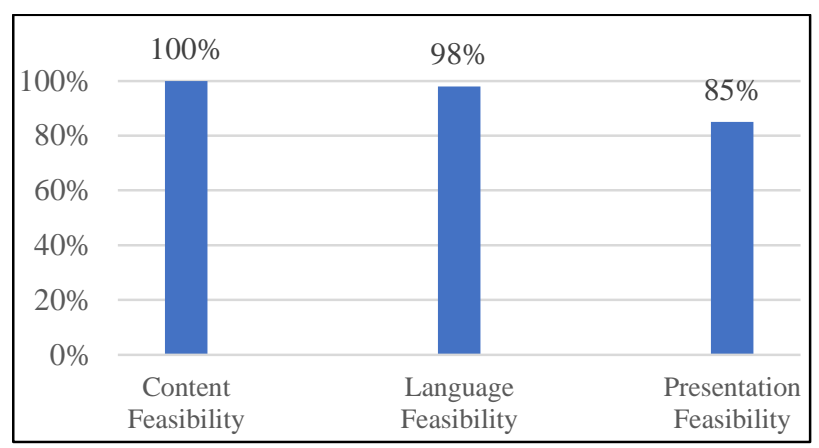

Figure 3. Percentage of characteristics of autistic children expert Justification

Based on the results of the validator's assessment in the field of expert characteristics of autistic children, the assessment is carried out based on the feasibility of content, language feasibility, and presentation feasibility, for content eligibility with a value of $100 \%$ it is in the "very valid" category than for language feasibility assessment it gets a score of $98 \%$ with a "very valid" category. valid ", and for the assessment of the feasibility of the presentation get a value of $85 \%$ with the category "very valid". With an average value of Rp. 5,000.00. The notes given by the validator are revamping the cover, the title needs to be conveyed, the title specification needs to be added to the type of student barriers, adjustment of the instructions for using the module for the teacher, the need for markers for barcode display and the use of instructions that need to be guided on the instructions, and display images need to be spaced

\section{Small-Group Trials}

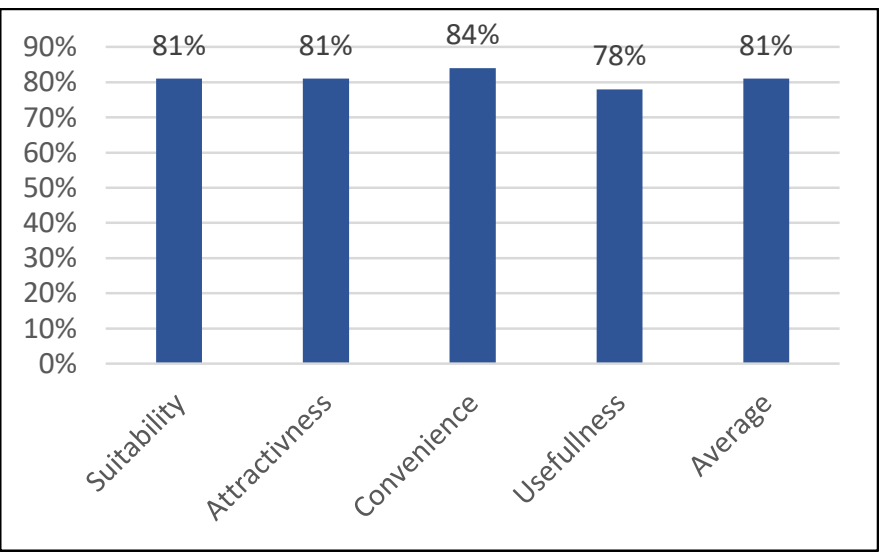

Figure 4. Percentage diagram of small group trials

The small group trial was carried out on the SLB Autism Laboratory of the State University of Malang with a total of 3 autistic students in the 3 rd 
grade of Special Education School. Then for a small group trial, the assessment instrument was given to 6 teachers at the SLB Autism Laboratory, State University of Malang. Based on the results of the product feasibility assessment by 6 teachers at the SLB Autism Laboratory, State University of Malang, each assessment contains the suitability, attractiveness, convenience, and usefulness where the assessment produces an average of $81 \%$ which is stated in the "very valid" category. Then from the results of suggestions or notes by the teacher, the product will be revised according to the input given before a large group trial is carried out.

\section{Large Group Trials}

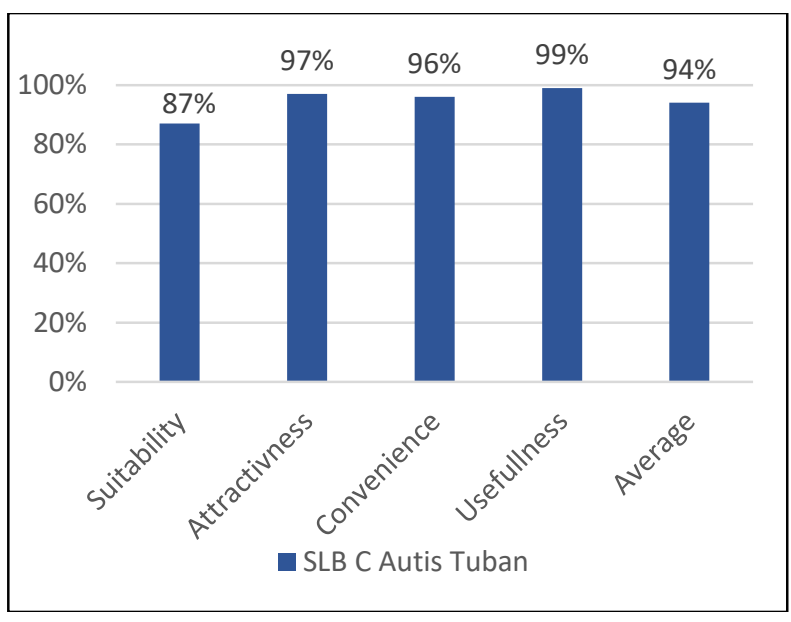

Figure 5. Diagram of Percentage of Large Group Trials

For the large group trial, the assessment instrument was given to 12 teachers at SLB C Autism Tuban. Based on the results of the product feasibility assessment by 12 teachers at SLB C Autism Tuban, each assessment contains the suitability, attractiveness, convenience, and usefulness of which the assessment produces an average of $94 \%$ which is stated in the "very valid" category. Then from the results of suggestions or notes by the teacher, the product will be revised according to the input given before proceeding to the final product.

\section{DISCUSSION}

Autism is defined by various opinions including mentioning that autism is a disorder of neurodevelopment in early childhood [14]. Children with autism are children with greater disturbances in motor aspects [15]. Autism is a complex neurodevelopmental disorder characterized by impaired social interaction, delayed and disorganized language, repetitive or stereotyped behavior, and a limited range of interests [16][17][18]. From this definition, it can be concluded that autism is a disorder in motor and neurobiological development that occurs in early childhood characterized by a series of disturbances in social interaction, communication skills, repetition or stereotyped behavior, and limited interests.

Classification for autistic children based on intellectual IQ is divided into 3, namely IQ below 50 is autistic which belongs to the moderate and severe group, IQ with numbers 50-70 belongs to autism with mild mental retardation, and IQ with numbers above 70 is an autistic group who does not have mental retardation [1]. Based on the classification in children with autism, the provision of movement activities is adjusted to the characteristics and limitations of the child's abilities. While the characteristics of movement in autistic children according to [1] children with autistic disorders tend to behave actively to hyperactive or passively to hypoactive, the movements that are often carried out are body swinging movements, swaying, flapping hands like birds, rotating movements suddenly, and the sudden change in silence with a blank stare. These changes in movement require good motor function in children.

Children with autism disorder have normal limbs but in the development of autistic children experience difficulties in understanding and disturbances in body coordination. Therefore, it is very important to provide assistance services to children with autism to realize the need for optimizing cognitive function and increasing the development of motor skills in learning. The need for movement activities is manifested in adaptive physical education. Adaptive physical education is an effort through movement activities that have been adapted to the growth and development of both physical and psychological children with limited special needs to achieve educational goals, namely the formation of a complete human being [19]. Providing physical activity through adaptive physical education for children with autistic disorders has positive benefits such as reducing anxiety, reducing stress, and improving poor sleep patterns [20][21]. Physical activity in children can reduce the risk of obesity and provide many physiological and psychosocial benefits [22][23][24]. And providing regular physical activity can reduce children's chances of developing cardiovascular disease [25]. Based on the above opinion, it is very important to provide assistance services to children with autism in the form of movement activities to avoid various diseases, form positive emotions and improve motor skills in children.

One of the needs of autistic children is the need for a component of physical fitness, namely balance. This opinion is supported by the results of research by [26] that postural stability or balance can affect a child's ability to perform gross motor skills. Balance is the ability to maintain the body's center of gravity [27]. Balance is a complex interaction of the 
combined sensory systems (tactile, visual, vestibular, and somatosensory including proprioceptors) and musculoskeletal (joints, muscles, and other soft tissues). Balance is divided into two, namely static balance which is the body's ability to be able to maintain its body balance in a stationary position for a certain period, and dynamic balance which is the body's ability to be able to maintain its body balance during daily activities [28]. Children with autism symptoms usually show poor motor skills and balance when compared to children in general autistic children are less involved in physical activity so that it has an impact on low fitness levels, overweight conditions, and obesity [29]. Dynamic balance disorders that occur in autistic children can be seen from the attitude of standing and walking that looks shaky, this is because autistic children tend to have poor coordination of the lower limbs in activities that require dynamic balance components.

Learning is a process where teachers or instructors provide guidance or assistance to students in carrying out the learning process [30]. Meanwhile, according to [31] learning is an interaction that occurs between teachers and students with the aim that students have a learning experience. In the learning process, a teacher requires learning media that can support the learning process to create an effective learning climate. Through learning media, it can make the teaching and learning process more effective and efficient and good relations are established between teachers and students [32]. One of the learning media that is often used in learning is a module, according to [33] A module is a learning tool that contains materials, methods, and steps that are systematically arranged and can be combined with various interesting media to achieve competence. which is expected. Making teaching media in the form of dynamic balance motion learning modules aimed at grade 3 teachers of Special Education School with autism, this development is the development of teaching media in the form of modules that contain Core Competencies and Basic Competencies for class 3 Special Education School, namely recognizing and practicing various variations of dynamic basic movement patterns (resisting, swinging, hovering in the air, turning, and landing) in simple gymnastic activities according to ability. Based on the diversity of classifications and characters of autistic children, the provision of movement activities through physical education requires the help of teaching media.

Research on the development of movement activity modules for autistic children in physical education learning is supported by the results of previous studies regarding movements in floor gymnastics that are suitable for improving dynamic balance in children. Fitness Fun Zone (FFZ) activities are carried out indoors on a mat in the form of a mat, through simple movements such as running on the spot, crunches, sit-ups, gorilla jumps, and so on. Have better results in increasing the physical activity of children with autistic disorders [34]. Through simple movement activities on the mat such as jumping, static balance, turning, crawling, and rolling over to the accompaniment of music rhythm can improve balance scores in children with autism disorders in motor aspects [35]. The results of research conducted by [36] stated that simple exercise patterns in the form of static movements, jumping, and rotating with eyes open influence balance ability Another study showed that a balance training program on unstable surfaces such as foam or foam with single leg stance and dynamic balance movements efficiently improved postural control in children with autism [8]. From some of the results of these studies, children with autism are essentially the same With normal children in general, which requires movement activities which are very important for the development of the stages of motion, the module creation has been adapted to the results of previous research which states that movement patterns such as jumping, jumping, rotating, and swinging have a positive influence on the development of dynamic balance in children. Barriers that often occur are in the pattern of communication, where the teacher or assistant must provide motivation and instructions in a short and easily understood by children.

The results of research on the development of teaching materials in the form of modules with dynamic balance material for students with autism grade 3 Special Education School have been compiled with very valid category results. In this study, psychological elements are needed, especially the motivation of a teacher to his students or the teacher's treatment of students greatly helps the level of understanding and confidence in children to dare to try, the movements in floor gymnastics include basic dynamic movements (refusing, swinging, hovering in the air, rotating, turning, swaying, swinging, landing) which has been prepared is equipped with a video tutorial in performing the movement. Therefore, the results of this research product can be used and applied in the learning process in the school environment.

\section{CONCLUSION}

Based on the results of data analysis in research on the development of dynamic balance motion modules in physical education subjects for grade Special Education School with autism, it can be concluded that the teaching materials in the form of these modules can answer problems caused by the lack of teaching materials used in the learning process. With the results of small group trials and large group trials, the validation of the feasibility of the module increases with very valid information. Based on these data, it can be concluded that the dynamic balance motion teacher 
module for grade 3 students of Special Education School with autism is very valid for use in learning. Similar research with other materials needs to be carried out to provide complete guidelines for teachers and students with autism to learn movement at school.

\section{REFERENCES}

[1] Siswantoyo and R. Oktavia, Terapi Aktivasi \& Relaksasi Olahraga Untuk Autisme, 1st ed. Yogyakarta: ANDI, 2018.

[2] F. D. Cahyanti and E. Hariyanto, "Upaya Meningkatkan Hasi Belajar Keterampilan Passing Atas Bolavoli Dalam Pembelajaran Pendidikan Jasmani Menggunakan Metode Bermain Untuk Siswa SMK," Sport Sci. Heal., vol. 3, no. 3 , pp. $133-141,2021$

[3] A. Hidayat, "Peningkatan Aktivitas Gerak Lokomotor, Nonlokomotor Dan Manipulatif Menggunakan Model Permainan Pada Siswa Sekolah Dasar," J. Pendidik. Jasm. Dan Olahraga, vol. 2, no. 2, p. 21, 2017

[4] H. Hadjarati and A. I. Haryanto, "Motivasi Untuk Hasil Pembelajaran Senam Lantai," Multilater. J. Pendidik. Jasm. dan Olahraga, vol. 19, no. 2, p. 137, 2020.

[5] B. G. Travers, A. H. Mason, K. G. Gruben, D. C. Dean, and K. McLaughlin, "Standing balance on unsteady surfaces in children on the autism spectrum: The effects of IQ," Res. Autism Spectrum. Disord., vol. 51, no. 1, pp. 9-17, 2018.

[6] S. A. Graham, A. E. Abbott, A. Nair, A. J. Lincoln, R. A. Müller, and D. J. Goble, "The Influence of Task Difficulty and Participant Age on Balance Control in ASD," J. Autism Dev. Disord., vol. 45, no. 5, pp. 1419-1427, 2015.

[7] J. F. Stins, C. Emck, E. M. de Vries, S. Doop, and P. J. Beek, "Attentional and sensory contributions to postural sway in children with autism spectrum disorder," Gait Posture, vol. 42, no. 2, pp. 199-203, 2015.

[8] H. Cheldavi, S. Shakerian, S. N. Shetab Boshehri, and M. Zarghami, "The effects of balance training intervention on postural control of children with autism spectrum disorder: Role of sensory information," Res. Autism Spectrum. Disord. vol. 8, no. 1, pp. 8-14, 2014.

[9] K. Oktaria and A. W. Nugroho, "Pengembangan Modul Pembelajaran Penjasorkes Melalui Aktivitas Jelajah Alam Sekitar Sekolah (AJASS) Bagi Anak Tunarungu Tingkat Sekolah Dasar Luar Biasa (SPECIAL EDUCATION SCHOOL ) Sekota Bandar Lampung," TERAMPIL J. Pendidik. dan Pembelajaran Dasar, vol. 6, no. 2, p. 55, 2019.

[10] M. Hartoto, D. Mulyono, W. Syafutra, and L. Linggau, "Pengembangan modul pembelajaran atletik berbantuan QR code Development of athletic learning modules assisted by QR code," Edu Sport. Indones. J. Phys. Educ., vol. 2, no. 1, pp. 51-60, 2021

[11] Y. T. Widayati, "Aplikasi Teknologi QR ( Quick Response ) Code Implementasi Yang Universal," KOMPUTAKI, vol. 3, no. 1, p. 130,2017

[12] R. M. Branch, Approach, Instructional Design: The ADDIE, vol. 53 , no. 9.2009.

[13] Sugiyono, Metode Penelitian Kuantitatif, Kualitatif, dan $R \& D$. Bandung: Alfabeta, 2016.

[14] M. B. Lauritsen, "Autism spectrum disorders," Eur. Child Adolesc. Psychiatry, vol. 22, no. 1, pp. 37-43, 2013.

[15] M. J. Weiss, M. F. Moran, M. E. Parker, and J. T. Foley, "Gait analysis of teenagers and young adults diagnosed with autism \& severe verbal communication disorders," Front. Integer. Neurosci., vol. 7, no. 33, pp. 1-10, 2013

[16] D. L. Coury et al., "Gastrointestinal conditions in children with autism spectrum disorder: Developing a research agenda," Pediatrics, vol. 130, no. 2, 2012.

[17] S. A. Linkenauger, M. D. Lerner, V. C. Ramenzoni, and D. R. Proffitt, "A perceptual-motor Deficit Predicts Social and Communicative Impairments in Individuals With Autism Spectrum
Disorders," Autism Res., vol. 5, no. 5, pp. 352-362, 2012.

[18] R. Downey and M. J. K. Rapport, "Motor activity in children with autism: A review of current literature," Pediatr. Phys. Ther., vol. 24, no. 1, pp. 2-20, 2012.

[19] J. Taufan, Ardisal, Damri, and Arise, "Pelaksanaan Pembelajaran Pendidikan Jasmani Adaptif bagi Anak dengan Hambatan Fisik dan Motorik," J. Pendidik. Kebutuhan Khusus, vol. 2, no. 2, p. 19, 2018

[20] A. Hillier, A. Buckingham, and D. Schena, "Physical Activity Among Adults With Autism: Participation, Attitudes, and Barriers," Percept. Mot. Skills, vol. 127, no. 5, pp. 874-890, 2020.

[21] M. A. Elmagd, "Benefits, need and importance of daily exercise," Int. J. Phys. Educ. Sport. Heal., vol. 3, no. 5, pp. $22-27,2016$

[22] A. P. Hills, D. R. Dengel, and D. R. Lubans, "Supporting Public Health Priorities: Recommendations for Physical Education and Physical Activity Promotion in Schools," Prog. Cardiovasc. Dis., vol. 57, no. 4, pp. 368-374, 2015.

[23] C. Curtin, M. Jojic, and L. G. Bandini, "Obesity in children with autism spectrum disorder," Harv. Rev. Psychiatry, vol. 22, no. 2, pp. 93-103, 2014.

[24] A. M. Egan, M. L. Dreyer, C. C. Odar, M. Beckwith, and C. B. Garrison, "Obesity in young children with autism spectrum disorders: Prevalence and associated factors," Child. Obes., vol. 9, no. 2, pp. 125-131, 2013.

[25] G. F. Fletcher, C. Landolfo, J. Niebauer, C. Ozemek, R. Arena, and C. J. Lavie, "Promoting Physical Activity and Exercise: JACC Health Promotion Series," J. Am. Coll. Cardiol., vol. 72, no. 14, pp. 1622-1639, 2018.

[26] M. A. Mache and T. A. Todd, "Gross motor skills are related to postural stability and age in children with autism spectrum disorder," Res. Autism Spectrum. Disord., vol. 23, pp. 179$187,2016$.

[27] L. J. Distefano, M. A. Clark, and D. A. Padua, "Evidence Supporting Balance Training In Healthy Individuals: A Systemic Review," J. Strength Cond. Res., vol. 23, no. 9, pp. 2718-2731, 2009.

[28] H. Tauhidman and G. Ramadan, "Pengembangan Model Latihan Keseimbangan Untuk Sekolah Dasar," J. Sport. J. Penelit. Pembelajaran, vol. 4, no. 1, pp. 133-144, 2018.

[29] S. M. McCoy and K. Morgan, "Obesity, physical activity, and sedentary behaviors in adolescents with autism spectrum disorder compared with typically developing peers," Autism, vol. 24 , no. 2 , pp. 387-399, 2020 .

[30] A. Pane and M. Darwis Dasopang, "Belajar Dan Pembelajaran," FITRAHJurnal Kaji. Ilmu-ilmu Keislam., vol. 3, no. 2, p. 333, 2017.

[31] R. Abdullah, "Pembelajaran Berbasis Pemanfaatan Sumber Belajar," J. Ilm. Didakt., vol. 12, no. 2, pp. 216-231, 2012.

[32] T. Tafonao, "Peranan Media Pembelajaran Dalam Meningkatkan Minat Belajar Mahasiswa," J. Komun. Pendidik., vol. 2, no. 2, p. 103, 2018.

[33] R. Linda, H. Herdini, S. Ika Sulistya, and T. P. Putra, "Interactive E-Module Development through Chemistry Magazine on Kvisoft Flipbook Maker Application for Chemistry Learning in Second Semester at Second Grade Senior High School," J. Sci. Learn., vol. 2, no. 1, p. 21, 2018.

[34] K. Brazendale, A. Randel, C. A. Sorenson, and R. G. Weaver, "Increasing physical activity in youth with Autism and other Developmental Disabilities in physical education," Researchgate.Net, vol. 2, no. 1, p. 122, 2019.

[35] B. Akyol and S. Pektaş, "The Effects of Gymnastics Training Combined With Music in Children with Autism Spectrum Disorder and Down Syndrome," Int. Educ. Stud., vol. 11, no. 11, p. 46, 2018

[36] J. Shavikloo, A. asghar Norasteh, and K. Irandoust, "The effect of integrative neuromuscular training on postural control of children with autism spectrum," Neurol. Neurosurg., vol. 1, no. 2, pp. 1-, 2018. 